Bull. Chem. Soc. Ethiop. 2014, 28(2), 229-244.

Printed in Ethiopia

ISSN 1011-3924

DOI: http://dx.doi.org/10.4314/bcse.v28i2.7

(C) 2014 Chemical Society of Ethiopia

\title{
CORRELATION AMONG FLUORIDE AND METALS IN IRRIGATION WATER AND SOILS OF ETHIOPIAN RIFT VALLEY
}

\author{
Elias Gizaw, Bhagwan Singh Chandravanshi* and Feleke Zewge \\ Department of Chemistry, Addis Ababa University, P. O. Box 1176, Addis Ababa, Ethiopia
}

(Received August 11, 2013; revised January 27, 2014)

\begin{abstract}
The levels of fluoride and selected metals in Ethiopian Rift Valley soils and irrigation water in the nearby sources were determined by fluoride ion selective electrode and flame atomic absorption spectrophotometer, respectively. The $\mathrm{pH}$, conductivity, salinity and total dissolved solids in water and soil samples were also determined. Accuracy of the optimized procedure was evaluated using standard addition (spiking) method and an acceptable percentage recovery was obtained. The fluoride concentrations in water samples were found in the range of $0.14-8.0 \mathrm{mg} / \mathrm{L}$ which is below the WHO limit of fluoride concentration for irrigation (less than $10 \mathrm{mg} / \mathrm{L}$ ). The water soluble and total fluorides in soil were 2.3-16 $\mu \mathrm{g} / \mathrm{g}$ and $209-1210 \mu \mathrm{g} / \mathrm{g}$, respectively and are within the ranges recommended by FAO and WHO. The range of metal concentration in soil samples $(\mu \mathrm{g} / \mathrm{g}$ dry weight basis) and in water samples $(\mathrm{mg} / \mathrm{L})$ respectively were: $\mathrm{Na}(684-6703,8.6-67), \mathrm{Mg}$ (1608-11229, 23-67), K (1776-4394, 1.1-20), Ca (7547-22998, 17-267), Cr (9.8-79, 0.07-0.17), Mn (143-700, $0.05-37)$, Co (50-112, 0.35-1.5), Ni (446-1288, 0.27-41), Fe (12180-32681, 6.0-48), Cu (8.9-45, 0.09-0.25) and

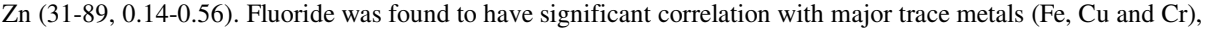
but the correlation with other trace metals was not significant.
\end{abstract}

KEY WORDS: Fluoride, Metals, Water, Soil, Ethiopia

\section{INTRODUCTION}

Fluoride has beneficial effects at low concentrations (less than about $2 \mathrm{mg}$ daily intakes) in drinking water, and other sources, when teeth are being formed; fluoride safely strengthens the enamel, the hard outer 'shell' of the tooth. This, in turn, stops cavities from forming and teeth from decaying. However, taken in quantity (just over $2 \mathrm{mg}$ of fluoride) is extremely toxic and dangerous. Fluoride can be one of the most volatile and active harmful chemicals in the body. Fluoride can attack mercilessly, against any age group, but its effects are especially harmful to developing children and the elderly. The detrimental effects of fluoride are varied [1].

Fluorides are released into the environment naturally through the weathering of minerals, in emissions from volcanoes and in marine aerosols. The main natural source of inorganic fluorides in soil is the parent rock. Anthropogenic sources of fluoride into the environment include the following: the industrial production and use of chemicals and phosphate fertilizers. Phosphate fertilizers are the major source of fluoride contamination of agricultural soils [1]. Available quantitative information concerning the release of fluoride into the environment (air, water and soil) from industrial sources is limited. Fluoride is released into the environment via exhaust fumes, process waters and waste from various industrial processes [1]. The uses of fluoride-containing pesticides as well as the fluoridation of drinking-water supplies also contribute to the release of fluoride from anthropogenic sources [1].

The fluoride content of soil is largely dependent on the mineralogical composition of the soil inorganic fraction. Fluoride solubility may be related to the solubility of Al or other ionic species with which it forms complexes. Although exceptions occur, a soil developed in the arid zone is usually more highly weathered than one developed in the humid tropical zone, due to high temperatures [2].

*Corresponding author. E-mail: bscv2006@yahoo.com 
The Ethiopian Rift System extends from the Kenyan border up to the Red Sea and is divided into four sub-systems: Lake Rudolf, Chew Bahir, the Main Ethiopian Rift (MER) and the Afar. The seismically active MER transects the uplifted Ethiopian plateau for a distance of $1000 \mathrm{~km}$, extending from the Afar Depression southwards across the broad zone of basins and volcanic ranges to the watershed of Lake Chamo. This study focuses on the MER [3].

The largest commercial farms in the country are present downstream of the Koka dam irrigated by the regulated flow of the Awash River which drains through the rift starting from the central highlands through the northern part of the MER and finally ending in Lake Abhe at the border with Djibouti. Out of the Awash Basin, Meki and Katar rivers and Lake Ziway are also used for irrigation [3].

The volcanic base-rock in the African Rift System is predominantly alkaline, and rich in e.g. sodium and fluoride. The soil produced by the weathering of these rocks is similarly rich in fluoride. After precipitation, however, rainwater leaches fluoride from soils as well as from crystalline rocks. The surface waters of East Africa, therefore, usually have high fluoride concentrations. Fluoride content in the water of various areas of the Ethiopian Rift Valley has been reported in range of $0.40-36.0 \mathrm{mg} / \mathrm{L}[4,5]$. Furthermore, since the hydrochemistry of aquifers is strongly influenced by the surrounding lithology, the fluoride content of ground water of Rift Valley is high, frequently to the extent that the waters are rendered unfit for human consumption.

Several studies have been carried out on determination of the levels of fluoride in waters of Ethiopian Rift Valley [4, 5] and different methods of defluoridation techniques [5, 6]. Source and distribution pattern fluoride in Ethiopian Rift Valley water [7, 8], fluoride binding capacity of different types of Ethiopian Rift Valley soils and search for the soil best fit for fluoride removal in high fluoride waters $[9,10]$ have also been reported. Studies have also been carried out on the status of selected metals in Rift Valley soil [11] and environmental problems and water resources utilization of the area [12]. Recently studies have also been conducted on fluoride exposure through food and beverages $[13,14]$ and khat chewing leaves $[15]$ and on the levels of metals in irrigation waters in Ethiopia [16-18].

However, there is no report in the literature indicating the levels of fluoride in Ethiopian Rift Valley soils and its correlation with the levels of metals. Therefore, this study was planned to generate a database for fluoride levels in soils and its correlation with metals concentration. The main objectives of this study were to determine the levels of fluoride in Ethiopian Rift Valley soils including: (i) to correlate the soil properties like $\mathrm{pH}$, conductivity, salinity and TDS with the fluoride contents of Ethiopian Rift Valley soil and (ii) to correlate the fluoride concentration in soil and nearby water sources used for irrigation.

\section{EXPERIMENTAL}

\section{Instrumentation}

Orion $\mathrm{F}$ ion selective electrode was used for the determination of $\mathrm{F}^{-}$ion in soil and water samples. A pH/ISE meter (Orion Model, EA 940 Expandable Ion Analyzer, USA) equipped with combination fluoride-selective electrode (Orion Model 96-09, USA) was employed. The $\mathrm{pH}$ was measured with $\mathrm{pH} /$ ion meter (WTW Inolab pH/ION Level 2, Germany) using unfilled $\mathrm{pH}$ glass electrode. The electrical conductivity (EC), salinity and total dissolved solids (TDS) of soil and water samples were measured using Thermo Orion EC meter (USA). Flame atomic absorption spectrophotometer (Buck Scientific Model 210VGP AAS, East Norwalk, USA) equipped with deuterium arc background correctors and hollow cathode lamps with airacetylene flame was used for the determination of the metals in soil and water samples. 


\section{Chemicals and reagents}

Chemicals and reagents that were used in the analysis were all analytical grade. Sodium fluoride (99.0\% NaF, BDH Chemicals Ltd, England) was used to prepare fluoride stock standard solution. Glacial acetic acid $(99.5 \%, \mathrm{BDH}$, England), sodium chloride (Scharlau, European Union), sodium citrate (Research-Lab Fine Chem. Industries Mumbai, India) and EDTA (Reagent grade, Spain) to prepare total ionic strength adjustment buffer (TISAB) solution, sodium hydroxide (Scharlau, European Union) solution to adjust $\mathrm{pH}$ of TISAB solution and total fluoride determination were also used. A $0.01 \mathrm{M}$ potassium chloride (A.R. Interchem, UK) was used for calibration of EC meter. $\mathrm{HNO}_{3}$ (69-72\%) (Research-Lab Fine Chem Industries Mumbai, India) were used for acidification of water sample for metal analysis. Aqua-regia prepared from 3:1 ratio of $37 \% \mathrm{HCl}$ (Riedel-deHaen, Germany) and (69-72\%) $\mathrm{HNO}_{3}$, and extra pure hydrogen peroxide $30 \% \mathrm{H}_{2} \mathrm{O}_{2}$ (Scharlau, European Union) were used for digestion of soil sample. $37 \% \mathrm{HCl}$ (Riedel-de-Haen, Germany) were also used for neutralization of fusion cake in total fluoride determination. Lanthanum nitrate hydrate (98\%, Aldrich, USA) was used to avoid refractory interference (for releasing calcium and magnesium from their phosphates). Stock standard solution of concentration $1000 \mathrm{mg} / \mathrm{L}$ in $2 \% \mathrm{HNO}_{3}$ of the metals, $\mathrm{Na}, \mathrm{K}, \mathrm{Ca}, \mathrm{Mg}$, $\mathrm{Mn}, \mathrm{Cu}, \mathrm{Zn}, \mathrm{Co}, \mathrm{Cr}, \mathrm{Fe}$ and $\mathrm{Ni}$ (Buck Scientific Puro-graphic) as nitrate salt were used to prepare intermediate standard solutions of metals. Distilled-deionized water (chemically pure with conductivity $\leq 1.5 \mu \mathrm{s} / \mathrm{cm}$ ) was used for dilution of sample and intermediate standard solutions prior to analysis and rinsing glassware and sample bottles.

\section{Sampling areas}

Samples were collected from fluoride rich Ethiopian Rift Valley irrigation and vegetation farm lands namely Bulbulla, Adami-Tullu, Zuway, Meki, Alem-Tena, Mojo, Wonji, Debre-Zeyt, and Akaki. Potable water from the Arat Kilo Campus of Addis Ababa University was used as a control. Except Akaki and the Addis Ababa University, all the other sampling sites are located in the East Shoa zone of Oromia Region, southeast of Addis Ababa. The area is known to encompass various water bodies used for irrigation such as rivers like Bulbulla, Meki and Awash River and lakes like Zuway, Debre-Zeyt and Koka Dam.

The area is under continuous cultivation throughout the year and has been supplying significant portion of a wide variety of vegetables like tomato, onion, cabbage, green pepper, potato, etc. to the capital city and for local consumption for a long period of time. Modern farming practices such as mechanized farming, application of agro-chemicals and selected seeds are significant agricultural inputs for getting better yield in the area.

\section{Sample collection and pretreatment}

The soil samples were collected from the surface horizon $(0-20 \mathrm{~cm})$ depth of the nine sampling areas of the Rift Valley vegetation farmlands and one control sample site. Sampling was done by taking half kilogram of soil from five sub-sites located roughly $3 \mathrm{~km}$ apart, homogenized to form one bulk sample, and one kilogram sub-sample of the homogenized soil was put in labeled clean polyethylene plastic bags and brought to the laboratory for further pre-treatment. The same procedure was followed for all the ten soil samples.

For comparative analysis of fluoride and metals in soil and water, water samples were collected from the water sources used for irrigation (river, lake and well) at the point where the water enters in to the farm plots. From each of the five sub-sites about one liter of water was collected and mixed to form one bulk sample. About $2 \mathrm{~L}$ of the composite sample was transferred in to labeled, pre-cleaned plastic bottles after rinsing with the water sample and 
brought to the laboratory for further pre-treatment. The same procedure was followed for all the nine water samples.

The soil samples collected from the ten sampling areas were air dried to constant weight for fifteen days, the air dried samples were ground using mortar and pestle and sieved through a 1.4 $\mathrm{mm}$ polyethylene sieve to remove large debris, stones, and pebbles. The part of the sample which passes through the sieve was collected in to the plastic bag and stored for the analysis.

The collected water samples were transported to the laboratory within 8 hours for measurement of fluoride concentration and other parameters including $\mathrm{pH}$, conductivity, salinity and total dissolved solids without any pre-treatment. $500 \mathrm{~mL}$ of water samples were filtered and preserved in $2 \%(\mathrm{v} / \mathrm{v})$ nitric acid and stored at about $4{ }^{\circ} \mathrm{C}$ in a refrigerator for metal analysis.

The total soil fluoride was determined using alkaline fusion by slightly modifying the reported methods [12]. $0.50 \mathrm{~g}$ of prepared soil samples were precisely weighed directly into the $50 \mathrm{~mL}$ nickel crucibles and moistened with $1 \mathrm{~mL}$ distilled water. To the moistened sample, 6.0 $\mathrm{mL}$ of a $17 \mathrm{M}$ sodium hydroxide solution was added and the contents placed in an oven (150 ${ }^{\circ} \mathrm{C}$ ) for $2 \mathrm{~h}$ until the sodium hydroxide had solidified. The crucible containing the dry ample was removed from the oven and transferred in to a muffle furnace for fusion at $600{ }^{\circ} \mathrm{C}$ for $30 \mathrm{~min}$ [19]. After cooling for $1 \mathrm{~h}, 15 \mathrm{~mL}$ of deionized water was added to the sample and the contents heated on a hot plate for approximately $3 \mathrm{~h}$ to facilitate the dissolution of the fusion cake. About $7 \mathrm{~mL}$ of concentrated hydrochloric acid was added drop wise to decrease the $\mathrm{pH}$ from 12.0-13.0 to 8.0-8.5 while continuously monitoring with a $\mathrm{pH}$ meter. Subsequently the samples were transferred to a $50 \mathrm{~mL}$ plastic volumetric flask. The crucible was rinsed successively with deionized water until the final volume reached $50 \mathrm{~mL}$ and all the washings were mixed and filtered with Whatman filter paper $(70 \mathrm{~mm}$, diameter) in pre-cleaned and rinsed $50 \mathrm{~mL}$ plastic volumetric flask. This step eliminates most of the $\mathrm{Al}$ and $\mathrm{Fe}$, both interfering in $\mathrm{F}$ determinations by the ion selective electrode. Before measuring the $\mathrm{F}^{-}, 10.0 \mathrm{~mL}$ total ionic strength adjusting buffer (TISAB) was added to $10.0 \mathrm{~mL}$ filtrate into $50 \mathrm{~mL}$ plastic beaker [19].

The stirring time for the extraction of water-soluble fluoride was optimized by varying the stirring time from $5 \mathrm{~min}$ to $2 \mathrm{~h}$ on one soil sample. A stirring time of $1 \mathrm{~h}$ was found to be optimum for the extraction of water soluble fluoride from soil samples. Using the optimized stirring time $(1 \mathrm{~h})$ the samples were prepared as follow: $5 \mathrm{~g}$ of prepared soil was weighed in 50 $\mathrm{mL}$ conical flask, $10 \mathrm{~mL}$ of deionized water added, the contents stirred by magnetic stirrer for 1 $\mathrm{h}$, the mixture filtered with Whatman No. 70 filter paper, the filtrate collected in $50 \mathrm{~mL}$ volumetric flask and diluted to volume. $10 \mathrm{~mL}$ of the clear supernatant was mixed with $10 \mathrm{~mL}$ TISAB in $50 \mathrm{~mL}$ plastic beaker and the $\mathrm{F}$ ion concentration of the solution was measured with an fluoride sensitive ISE against $\mathrm{NaF}$ standards.

Applying the optimized condition [20], $0.5 \mathrm{~g}$ of dried and homogenized soil samples were transferred into a $100 \mathrm{~mL}$ round bottomed flask. To this $6 \mathrm{~mL}$ of aqua-regia (3:1 ratio of $37 \%$ $\mathrm{HCl}$ to $(69-72 \%) \mathrm{HNO}_{3}$ ) and followed by $1.5 \mathrm{~mL}$ of $30 \% \mathrm{H}_{2} \mathrm{O}_{2}$ were added and the mixture was digested on a Kjeldahl digestion apparatus fitting the flask to a reflux condenser by setting the temperature first to dial at $6\left(180^{\circ} \mathrm{C}\right)$ for the first $30 \mathrm{~min}$ and then raised to dial $8\left(240{ }^{\circ} \mathrm{C}\right)$ for the next $30 \mathrm{~min}$ and finally raised to dial $9\left(270{ }^{\circ} \mathrm{C}\right)$ for the remaining $2 \mathrm{~h}$. The digest was allowed to cool to room temperature for $30 \mathrm{~min}$ without dismantling the condenser from the flask and for $30 \mathrm{~min}$ after removing the condenser. To the cooled solution $20 \mathrm{~mL}$ of deionized water was added to dissolve the precipitate formed on cooling and to minimized dissolution of filter paper by the digest residue while filtering with Whatman, $(70 \mathrm{~mm}$, diameter $)$, filter paper into $50 \mathrm{~mL}$ volumetric flask. The round bottom flask was rinsed subsequently with $5 \mathrm{~mL}$ deionized water until the total volume reached around $45 \mathrm{~mL}$. To this final solution, $2 \mathrm{~mL}$ lanthanum nitrate solution $(1 \% \mathrm{w} / \mathrm{w})$ was added and the solution was filled to the mark $(50 \mathrm{~mL})$ with deionized water. The digestion was carried out in triplicate for each bulk samples. Digestion of a reagent blank was also performed in parallel with the soil samples keeping all 
digestion parameters the same. The digested samples were kept in the refrigerator, until the level of all the metals in the sample solutions were determined by FAAS.

\section{Method validation}

The method validation was established by spiking experiments (recovery test). The spiked samples were prepared by adding known volumes of $20 \mathrm{mg} / \mathrm{L}$ standard fluoride solution for water soluble fluoride and total fluoride, respectively. The spiked and non-spiked soil samples were prepared and analyzed in a similar condition and the percentage recovery of the analyte was calculated.

Prepared soil samples weighing $5 \mathrm{~g}$ and $0.5 \mathrm{~g}$ for water soluble fluoride and total fluoride, respectively, were spiked with standard fluoride solution equivalent to $25 \%, 50 \%$, or $100 \%$ of the fluoride content of the original (unspiked) soil samples. Fluoride was determined in these spiked samples in triplicate.

The metal analysis method was validated by spiking experiments. The spiked samples were prepared by adding a small known quantity of metal standard solutions. For spiking soil sample, $100 \mu \mathrm{L}$ of $100 \mathrm{mg} / \mathrm{L} \mathrm{Ca}, \mathrm{Cr}, \mathrm{Co}, \mathrm{K}, \mathrm{Ni}, \mathrm{Mn}, \mathrm{Mg}, \mathrm{Na}$, and Fe, $100 \mu \mathrm{L}$ of $3 \mathrm{mg} / \mathrm{L} \mathrm{Cr}$ and $100 \mu \mathrm{L}$ of $0.4 \mathrm{mg} / \mathrm{L} \mathrm{Zn}$ standard solutions were added to round bottomed flask $(100 \mathrm{~mL})$ containing 0.5 $\mathrm{g}$ soil sample. The spiked and non-spiked samples were digested and analysed in similar condition. A $100 \mathrm{~mL}$ acidified and filtered water sample was spiked with $200 \mu \mathrm{L}$ portion of the same metal standards, described above.

The percentage recoveries for the studied metal nutrients in both the soil and water samples were within the acceptable range (91-105\%) in the soil and $(91-106 \%)$ in the water samples. Therefore, this verifies that the optimized digestion procedure and instrument was valid for soil sample analysis and the instrument was valid for water analysis.

\section{Fluoride determination in soil and water samples}

The liquid phase $\mathrm{F}$ concentrations were determined by mixing equal volumes $(10 \mathrm{~mL})$ of soil, water samples or standards with TISAB in a $50 \mathrm{~mL}$ plastic beaker and the mixture were stirred (uniformly) thoroughly using the magnetic stirrer. The combination fluoride selective electrode was immersed in the solution and calibrated the fluoride ion selective electrode prior to each experiment over a concentration range of interest $(0.1$ to $10 \mathrm{mg} / \mathrm{L}$ for water soluble fluoride and 0.5 to $20 \mathrm{mg} / \mathrm{L}$ for total fluoride determination in soil and water samples. The method of direct potentiometry was used and the concentration of fluoride was read directly. All measurements were made in triplicates.

Determination of $p H$, conductivity, salinity and total dissolved solid (TDS) in soil and water samples

Soil $\mathrm{pH}$, conductivity, salinity and TDS of prepared soil samples were determined by mixing 10 $\mathrm{g}$ of soil with $25 \mathrm{~mL}$ of deionized water in $50 \mathrm{~mL}$ Erlenmayer flask. The mixture was stirred by magnetic stirrer for $30 \mathrm{~min}$. Then $\mathrm{pH}$ was measured after calibrating the $\mathrm{pH}$ meter with technical $\mathrm{pH}$ buffer of 4.01 and $10.00 \mathrm{pH}$ value, the other three parameters (conductivity, salinity and TDS) were determined after direct calibration with $0.01 \mathrm{M}$ potassium chloride $(\mathrm{KCl})$ solution. For the water samples, all the parameters were determined by measuring $30 \mathrm{~mL}$ water sample in $50 \mathrm{~mL}$ plastic beaker. Triplicate measurements were done in constantly stirred solutions in order to homogenize the solution. 
Metal determination in soil and water samples

Flame atomic absorption spectrophotometer, FAAS, equipped with deuterium arc background corrector and standard air-acetylene flame system using external calibration curve after optimizing the parameters to give maximum signal intensity of the instrument was used for determination of metal of interest. Three replicate of each sample, blank and working standards of each metal were determined by the same procedure.

\section{RESULTS AND DISCUSSION}

\section{Distribution patterns of fluoride in soil samples}

The water soluble fluoride content in soil samples collected from the ten sample sites are presented in Table 1. The water soluble fluoride levels varied within the range of 2.3 to $16 \mu \mathrm{g} / \mathrm{g}$. The highest water soluble fluoride was obtained in the soil of Alem Tena and the lowest concentration was found in the control soil of Addis Ababa University Arat Killo Campus. The loading of fluoride on the soil arising from the use of the water for irrigation and fluoride from other sources has no negative effect on the human, because the water soluble fluoride is in the range of 2.6-16 $\mu \mathrm{g} / \mathrm{g}$ soil which are within range of water soluble fluoride recommendation of FAO, EPA, and WHO [1].

The total fluoride contents of the soil samples are presented in Table 1. The total fluoride levels varied from 209 to $1210 \mu \mathrm{g} / \mathrm{g}$. The highest total fluoride was measured in Bulbulla soil and the lowest concentration in the control soil of Arat Killo campus of the Addis Ababa University. Except three sample sites (Zuway, Adami Tulu and Bulbulla), a normal fluoride content of 150-400 $\mu \mathrm{g} / \mathrm{g}$ [21] was measured in all other soils. The exceeded values in the above three sample sites may be due to heavy clay type of soils or the acid igneous rocks that contain fluoride in the range $850-1000 \mu \mathrm{g} / \mathrm{g}$, are sources of surface soil or fluoride present in soils in the form of the following minerals: fluorite $-\mathrm{CaF}_{2}$; fluoroapatite $-\mathrm{Ca}_{10}\left(\mathrm{PO}_{4}\right)_{6} \mathrm{~F}_{2}$. These minerals are sparingly soluble in water, so that only small amounts of $\mathrm{F}^{-}$are taken up by plants.

Table 1. Mean concentration (mean $\pm \mathrm{SD}$ ) of fluoride, $\mathrm{pH}$, conductivity, salinity and total dissolved solid (TDS) of soil samples.

\begin{tabular}{|c|c|c|c|c|c|c|}
\hline $\begin{array}{c}\text { Sample } \\
\text { site }\end{array}$ & $\begin{array}{c}\text { Water } \\
\text { soluble } \\
\text { fluoride }(\mu \mathrm{g} / \mathrm{g}) \\
\text { mean } \pm \mathrm{SD}\end{array}$ & $\begin{array}{c}\text { Total fluoride } \\
(\mu \mathrm{g} / \mathrm{g}) \\
\text { mean } \pm \mathrm{SD}\end{array}$ & $\begin{array}{c}\mathrm{pH} \\
\text { mean } \pm \mathrm{SD}\end{array}$ & $\begin{array}{c}\text { Conductivity } \\
(\mu \mathrm{s}) \\
\text { mean } \pm \mathrm{SD}\end{array}$ & $\begin{array}{c}\text { Salinity } \\
(\% \mathrm{o}) \\
\text { mean } \pm \mathrm{SD}\end{array}$ & $\begin{array}{c}\text { Total } \\
\text { dissolved } \\
\text { solid (TDS) } \\
(\mathrm{mg} / \mathrm{L})\end{array}$ \\
\hline AAAK & $2.3 \pm 0.2$ & $209 \pm 25$ & $7.40 \pm 0.07$ & $163 \pm 2$ & $0.1 \pm 0.0$ & $77 \pm 0.6$ \\
\hline AK & $4.7 \pm 0.1$ & $224 \pm 7$ & $7.69 \pm 0.06$ & $155 \pm 3$ & $0.1 \pm 0.0$ & $73 \pm 0.6$ \\
\hline DZ & $4.1 \pm 0.4$ & $229 \pm 10$ & $6.53 \pm 0.02$ & $205 \pm 3$ & $0.1 \pm 0.0$ & $98 \pm 1$ \\
\hline MO & $3.5 \pm 0.7$ & $363 \pm 3$ & $7.36 \pm 0.07$ & $43 \pm 2$ & $0.0 \pm 0.0$ & $20 \pm 0.6$ \\
\hline WO & $11 \pm 0.2$ & $345 \pm 9$ & $8.02 \pm 0.02$ & $121 \pm 1$ & $0.1 \pm 0.0$ & $57 \pm 0.0$ \\
\hline AL & $16 \pm 3$ & $380 \pm 12$ & $7.90 \pm 0.02$ & $262 \pm 3$ & $0.1 \pm 0.0$ & $125 \pm 2$ \\
\hline ME & $5.5 \pm 0.3$ & $333 \pm 23$ & $7.59 \pm 0.04$ & $115 \pm 2$ & $0.1 \pm 0.0$ & $55 \pm 0.6$ \\
\hline ZU & $12 \pm 0.5$ & $662 \pm 11$ & $8.43 \pm 0.02$ & $487 \pm 6$ & $0.2 \pm 0.0$ & $233 \pm 2$ \\
\hline AD & $5.07 \pm 0.33$ & $669 \pm 17$ & $7.91 \pm 0.02$ & $134 \pm 8$ & $0.1 \pm 0.0$ & $64 \pm 4$ \\
\hline BU & $6.3 \pm 0.3$ & $1210 \pm 86$ & $8.23 \pm 0.03$ & $91 \pm 7$ & $0.0 \pm 0.0$ & $43 \pm 3$ \\
\hline
\end{tabular}

AAAK = Addis Ababa University, Arat Kilo Campus, AK = Akaki, DZ = Debre-Zeyt, MO = Mojo, WO = Wonji, $\mathrm{AL}=$ Alem-Tena, $\mathrm{ME}=$ Meki, $\mathrm{ZU}=$ Zuway, $\mathrm{AD}=$ Adami-Tullu, $\mathrm{BU}=$ Bulbulla . 


\section{Distribution patterns of fluoride in water samples}

As reported in Table 2, the highest fluoride concentration was found in Alem Tena irrigation dam water that is $8.0 \mathrm{mg} / \mathrm{L}$ and the lowest $(0.14 \mathrm{mg} / \mathrm{L})$ in the tap water of the Arat Kilo Campus of Addis Ababa University. According to the World Health Organization [22], fluoride more than $1 \mathrm{mg} / \mathrm{L}$ in drinking water becomes toxic to animals and human beings, and toxic to some crops and animals when present at more than $10 \mathrm{mg} / \mathrm{L}$ in irrigation waters. Except Alem Tena water, other water samples are safe for irrigation with low fluoride concentrations $(<2 \mathrm{mg} / \mathrm{L})$. Even, Alem Tena water is safe for irrigation since it is below the upper limit of WHO permissible level of fluoride for irrigation [22].

Table 2. Mean concentration (mean $\pm \mathrm{SD}$ ) of fluoride, $\mathrm{pH}$, conductivity, salinity and total dissolved solid (TDS) of water sample.

\begin{tabular}{|c|c|c|c|c|c|}
\hline $\begin{array}{c}\text { Sample } \\
\text { site }\end{array}$ & $\begin{array}{c}\text { Fluoride } \\
\text { concentration } \\
(\mathrm{mg} / \mathrm{L})\end{array}$ & $\begin{array}{c}\mathrm{pH} \\
\text { mean } \pm \mathrm{SD}\end{array}$ & $\begin{array}{c}\text { Conductivity } \\
(\mu \mathrm{s}) \\
\text { mean } \pm \mathrm{SD}\end{array}$ & $\begin{array}{c}\text { Salinity } \\
(\% \mathrm{SD}) \\
\text { mean } \pm \mathrm{SD}\end{array}$ & $\begin{array}{c}\text { Total dissolved } \\
\text { solid (TDS) } \\
(\mathrm{mg} / \mathrm{L}) \\
\text { mean } \pm \mathrm{SD}\end{array}$ \\
\hline AAAK & $0.14 \pm 0.002$ & $7.73 \pm 0.04$ & $103 \pm 1$ & $0.0 \pm 0.0$ & $49 \pm 0.6$ \\
\hline AK & $1.1 \pm 0.05$ & $7.79 \pm 0.03$ & $489 \pm 4$ & $0.2 \pm 0.0$ & $234 \pm 2$ \\
\hline DZ & $1.3 \pm 0.06$ & $7.62 \pm 0.03$ & $228 \pm 1$ & $0.1 \pm 0.0$ & $109 \pm 1$ \\
\hline MO & $1.5 \pm 0.09$ & $7.94 \pm 0.03$ & $540 \pm 1$ & $0.3 \pm 0.0$ & $259 \pm 1$ \\
\hline WO & $1.3 \pm 0.05$ & $8.08 \pm 0.02$ & $213 \pm 2$ & $0.1 \pm 0.0$ & $102 \pm 1$ \\
\hline AL & $8.0 \pm 0.3$ & $7.91 \pm 0.02$ & $832 \pm 6$ & $0.4 \pm 0.0$ & $401 \pm 3$ \\
\hline ME & $1.4 \pm 0.05$ & $7.91 \pm 0.02$ & $445 \pm 3$ & $0.2 \pm 0.0$ & $213 \pm 2$ \\
\hline ZU & $1.8 \pm 0.03$ & $7.85 \pm 0.02$ & $355 \pm 3$ & $0.2 \pm 0.0$ & $170 \pm 2$ \\
\hline AD & $1.9 \pm 0.02$ & $7.78 \pm 0.02$ & $352 \pm 2$ & $0.2 \pm 0.0$ & $168 \pm 1$ \\
\hline BU & $2.0 \pm 0.06$ & $8.04 \pm 0.12$ & $357 \pm 3$ & $0.2 \pm 0.0$ & $171 \pm 2$ \\
\hline
\end{tabular}

AAAK = Addis Ababa University, Arat Kilo Campus, AK = Akaki, DZ = Debre-Zeyt, MO = Mojo, WO = Wonji, $\mathrm{AL}=$ Alem-Tena, $\mathrm{ME}=$ Meki, $\mathrm{ZU}=$ Zuway, $\mathrm{AD}=$ Adami-Tullu, $\mathrm{BU}=$ Bulbulla.

\section{Distribution patterns of $\mathrm{pH}$, conductivity, salinity and TDS}

As reported in Table 1, the $\mathrm{pH}$ range lied between 6.53-8.43. The highest $\mathrm{pH}$ was found in Zuway soil and the lowest $\mathrm{pH}$ was found in Dedre-Zeyt soil. Thus, the $\mathrm{pH}$ of all soil samples is near to neutral. Therefore, in this $\mathrm{pH}$ range, fluoride solubility and the availability of fluoride for plant uptake is not significantly affected by $\mathrm{pH}$. The values of other three parameters are also given in Table 1 . The three parameters have positive correlation to each other. The highest value was found in Zuway that is $487 \mu \mathrm{s}$ conductivity, $0.2 \%$ of salinity and $233 \mathrm{mg} / \mathrm{L}$ of total dissolved solid (TDS) and the lowest was found in Mojo that is $43 \mu \mathrm{s}$ of conductivity, $0.0 \%$ of salinity and $20 \mathrm{mg} / \mathrm{L}$ of TDS. Did you mean $\%$ in $0.2 \% 0$ and $0.0 \% 0$.

As reported in Table 2, the $\mathrm{pH}$ range lied between 7.62 and 8.04 . The highest $\mathrm{pH}$ was found in Bulbulla water and the lowest $\mathrm{pH}$ was found in Dedre-Zeyt water. Thus, the $\mathrm{pH}$ of all water samples is near to neutral and in the range of the normal $\mathrm{pH}$ range for irrigation water 6.5-8.4. The values of other three parameters are also reported in Table 2. The three parameters have positive correlation to each other. The highest conductivity of $832 \mu \mathrm{s}$, salinity of $0.4 \%$ and total dissolved solid (TDS) of $401 \mathrm{mg} / \mathrm{L}$ was found in Alem Tena water, and the lowest in Addis Ababa Univsersity Arat Killo Campus tap water with $103 \mu$ s of conductivity, $0.0 \%$ of salinity and $49 \mathrm{mg} / \mathrm{L}$ of TDS.

Appropriate tests should be conducted prior to selecting irrigation water for plant growing. General guidelines for irrigation water used in plant production reported an optimum 
conductivity range of 0-300 $\mu \mathrm{S}$ and TDS in the range 0-192 $\mathrm{mg} / \mathrm{L}$ [23]. Except Wonji, DebreZeyt and Addis Ababa University Arat Killo Campus tap water, conductivity of others was above the optimum range of reported guidelines for irrigation waters. But, TDS of most waters are within the range except Akaki, Mojo, Alem-Tena and Meki water.

\section{Distribution patterns of metals in soil samples}

The soil samples collected from ten sampling sites were found to contain detectable major $(\mathrm{Ca}$, $\mathrm{Mg}, \mathrm{Na}$, and $\mathrm{K})$ and trace $(\mathrm{Cu}, \mathrm{Co}, \mathrm{Cr}, \mathrm{Mn}, \mathrm{Fe}, \mathrm{Zn}$ and $\mathrm{Ni})$ metals. There is significant difference in concentration of different metals within soil samples and appreciable difference in the level of same metals of different samples. The concentration ranges of metals from ten soil sampling areas are shown in Figure 1.

Macro elements and $\mathrm{Fe}$

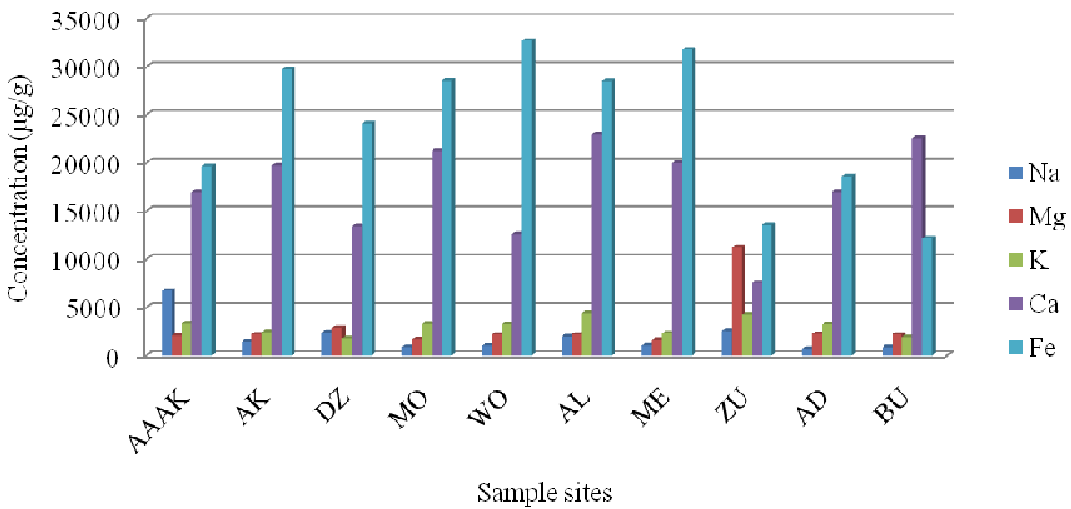

Trace metals

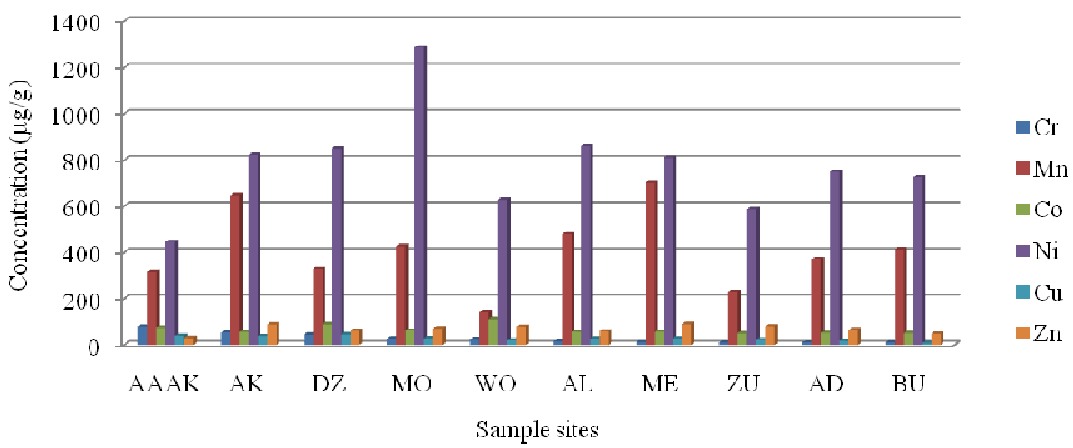

Figure 1. Distribution pattern of metals in soil sample (AAAK = Addis Ababa University, Arat Kilo Campus, $\mathrm{AK}=$ Akaki, $\mathrm{DZ}=$ Debre-Zeyt, $\mathrm{MO}=\mathrm{Mojo}, \mathrm{WO}=\mathrm{Wonji}, \mathrm{AL}=\mathrm{Alem}-$ Tena, $\mathrm{ME}=$ Meki, $\mathrm{ZU}=$ Zuway, $\mathrm{AD}=$ Adami-Tullu, $\mathrm{BU}=$ Bulbulla). 
Correlation among fluoride and metals in irrigation water and soils of Ethiopian Rift Valley 237

As shown in Figure 1, the concentration of Fe $(12180-32681 \mu \mathrm{g} / \mathrm{g})$ in soil exceeds the concentration of macro-elements, Ca (7547-22998 $\mu \mathrm{g} / \mathrm{g}), \mathrm{Mg}(1608-11229 \mu \mathrm{g} / \mathrm{g}), \mathrm{Na}(684-6703$ $\mu \mathrm{g} / \mathrm{g})$ and $\mathrm{K}(1776-4394 \mu \mathrm{g} / \mathrm{g})$, which could be due to the presence of excess amount of hematite $\left(\mathrm{Fe}_{2} \mathrm{O}_{3}\right)$ in the soil.

The micro-nutrient heavy metal $\mathrm{Ni}(446-1288 \mu \mathrm{g} / \mathrm{g})$ in this soil is higher compared to others Mn (143-700 $\mu \mathrm{g} / \mathrm{g}), \mathrm{Co}(50-112 \mu \mathrm{g} / \mathrm{g}), \mathrm{Zn}(31-89 \mu \mathrm{g} / \mathrm{g}), \mathrm{Cr}(9.8-79 \mu \mathrm{g} / \mathrm{g})$ and $\mathrm{Cu}(8.9-45 \mu \mathrm{g} / \mathrm{g})$. In general, the concentration pattern of metals in soil was decreased as $\mathrm{Fe}>\mathrm{Ca}>\mathrm{Mg}>\mathrm{Na}>\mathrm{K}$ $>\mathrm{Ni}>\mathrm{Mn}>\mathrm{Co}>\mathrm{Zn}>\mathrm{Cr}>\mathrm{Cu}$.

Macro elements and Fe

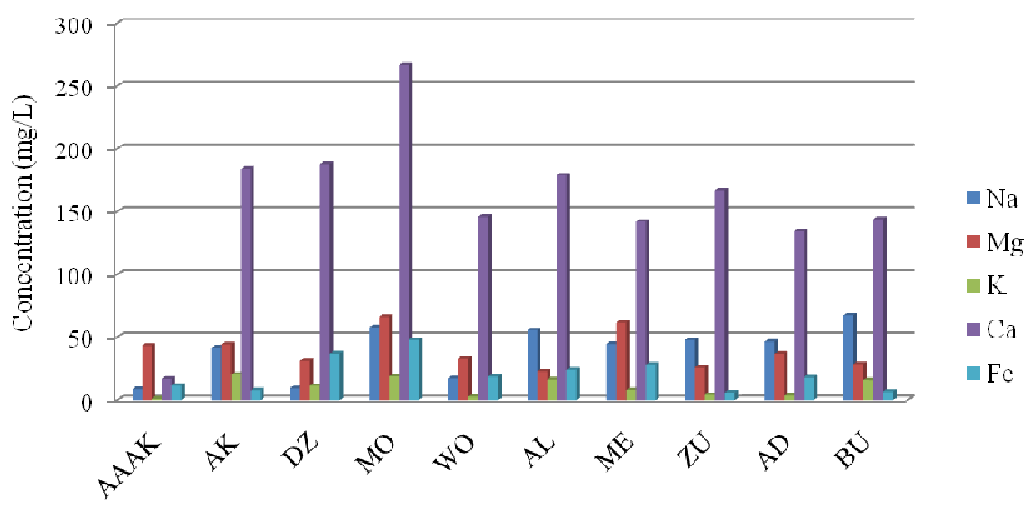

Sample sitcs

Trace metals

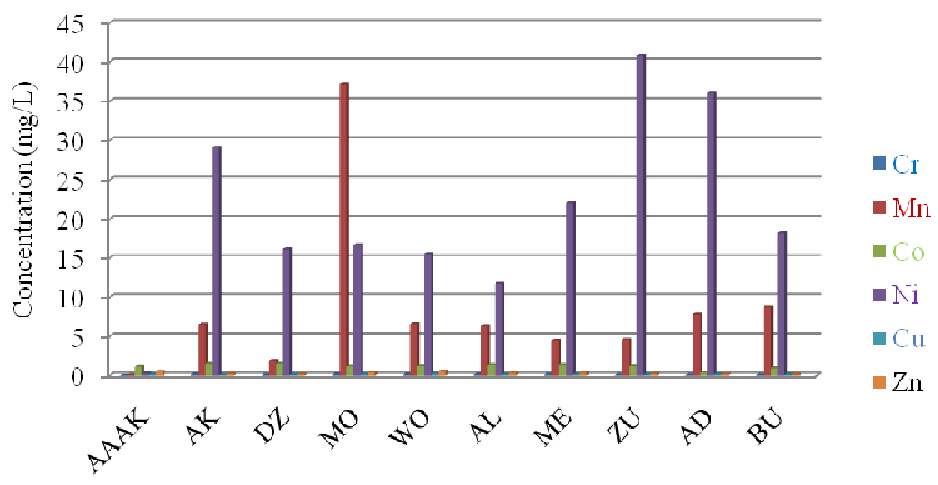

Sample sites

Figure 2. Distribution pattern of metals in water sample (AAAK = Addis Ababa University, Arat Kilo Campus, $\mathrm{AK}=$ Akaki, $\mathrm{DZ}=$ Debre-Zeyt, $\mathrm{MO}=\mathrm{Mojo}, \mathrm{WO}=\mathrm{Wonji}, \mathrm{AL}=\mathrm{Alem}-$ Tena, $\mathrm{ME}=$ Meki, $\mathrm{ZU}=$ Zuway, $\mathrm{AD}=$ Adami-Tullu, $\mathrm{BU}=$ Bulbulla). 
Distribution patterns of metals in water samples

The irrigation water sampled from lakes, rivers and wells at the point of diversion from pipes was also found to contain detectable metals $\mathrm{Na}, \mathrm{Ca}, \mathrm{Mg}, \mathrm{K}, \mathrm{Mn}, \mathrm{Cr}, \mathrm{Co}, \mathrm{Cu}, \mathrm{Fe}, \mathrm{Zn}$ and $\mathrm{Ni}$. Concentration of macro-element $\mathrm{Ca}(17-267 \mathrm{mg} / \mathrm{L})$ in this water samples are higher compared to other macro and micro-elements and the smallest is $\mathrm{Cr}(0.07-0.17 \mathrm{mg} / \mathrm{L})$. In general, the concentration pattern of metals in water was in decreasing order as $\mathrm{Ca}>\mathrm{Mg}>\mathrm{Na}>\mathrm{Fe}>\mathrm{Ni}>$ $\mathrm{Mn}>\mathrm{K}>\mathrm{Co}>\mathrm{Zn}>\mathrm{Cu}>\mathrm{Cr}$.

General guidelines for irrigation water used in plant production were also reported the optimum range of some metals; $\mathrm{Na}(0-30 \mathrm{mg} / \mathrm{L}), \mathrm{Ca}(40-100 \mathrm{mg} / \mathrm{L}), \mathrm{Mg}(5-25 \mathrm{mg} / \mathrm{L}), \mathrm{K}(1-10$ $\mathrm{mg} / \mathrm{L}), \mathrm{Fe}(1-3 \mathrm{mg} / \mathrm{L}), \mathrm{Mn}(0.2-1 \mathrm{mg} / \mathrm{L}), \mathrm{Zn}(0-0.2)$ and $\mathrm{Cu}(0.05-0.15 \mathrm{mg} / \mathrm{L})$ [23]. As shown in Figure 2 most of the metals in most of sample sites are above the optimum range.

\section{Correlation of fluoride between water and soil samples}

All the soil samples were collected from the irrigation farm lands of Ethiopian Rift Valley and the corresponding water sample were collected from the nearby water sources used for irrigation. The water soluble fluoride concentrations in soil samples have two major sources; one is from rapidly soluble fluoride complex like cryolite $\left(\mathrm{Na}_{3} \mathrm{AlF}_{6}\right)$ found in water and soil and the second is from phosphate fertilizers.

Except Addis Ababa University Arat Killo Campus soil used as control group and the tap water, in all the other samples the fluoride concentration in water samples are higher than in soil sample; this may be due to soluble fluoride is washed by soil erosion in to the water sources like river, lake and well. Fluoride concentrations in water have positive correlation with both total and water soluble fluoride in soil; but the degree of correlation between fluoride in water and water soluble fluoride in soil is strong (correlation coefficient, $r=0.80, p=0.006$ ) and the degree of correlation between fluoride in water and total fluoride in soil is very weak $(r=0.16$, $\mathrm{p}=0.675$ ). Therefore, the levels of fluoride in water are more depend on the contents of water soluble fluoride in soil than total fluoride found in soil.

\section{Correlation of water soluble and total fluoride in soil samples}

Significant differences between the investigated soils have been obtained for water soluble fluoride content, which amounts from 2.3 to maximum $16 \mathrm{mg} / \mathrm{kg}$. As shown in Table 3, water soluble fluoride is expressed in percentage from the total fluoride content; obtained values are much lower and are in the range from 0.52 to $4.3 \%$. Therefore, relative to total, lower water soluble fluoride content in the investigated soil samples was obtained. Different soils can bind different amounts of soluble fluoride as well as precipitation of $\mathrm{F}^{-}$with $\mathrm{Ca}^{2+}$ in solution and/or the complexing of $\mathrm{Ca}-\mathrm{F}$ in the soil have been suggested as reasons for decreased fluoride solubility. Also, fluoride availability is much more dependent on soil's capacity for its bounding than on total fluoride content. For that reason, statistically small correlation coefficient between the total and water soluble fluoride content has been obtained $(r=0.14, p=0.693)$.

Table 3. Percentage of total fluoride that is extracted with water from the soil samples.

\begin{tabular}{|l|l|l|l|l|l|l|l|l|l|l|}
\hline Sample site & AAAK & AK & DZ & MO & WO & AL & ME & ZU & AD & BU \\
\hline $\begin{array}{l}\text { \% Fluoride } \\
\text { extracted }\end{array}$ & 1.1 & 2.1 & 1.8 & 0.96 & 3.1 & 4.3 & 1.7 & 1.7 & 0.76 & 0.52 \\
\hline
\end{tabular}

AAAK $=$ Addis Ababa University, Arat Kilo Campus, $\mathrm{AK}=$ Akaki, $\mathrm{DZ}=$ Debre-Zeyt, $\mathrm{MO}=\mathrm{Mojo}, \mathrm{WO}=$ Wonji, $\mathrm{AL}=$ Alem-Tena, $\mathrm{ME}=$ Meki, $\mathrm{ZU}=$ Zuway, $\mathrm{AD}=$ Adami-Tullu, $\mathrm{BU}=$ Bulbulla. 
Correlation of fluoride with $\mathrm{pH}$, conductivity, salinity and TDS

In this study, the $\mathrm{pH}$ of all soil samples was found to be more than 6.53 and extends to neutral and slightly alkaline. Therefore, there is no significant effect of $\mathrm{pH}$ on fluoride solubility in top soils of collected soil samples.

The maximum values of conductivity, salinity and TDS were found in Alem Tena water, it also contained the highest concentration of fluoride and the lowest concentration were obtained in the soil of Addis Ababa Arat Killo campus. The corelation coffecent between fluoride and the three parametrs are $(r=0.82, p=0.004, r=0.78, p=0.008)$, fluoride with conductiviy, salinity and TDS respectivily in water sample. Therefore, all the three parametrs are strong positive correlation with fluoride in water sample.

The relations between total fluorides concentrations with the three parameters are not significant. The correlation coefficients are $(r=0.04, p=0.925, r=-0.28, p=0.427, r=0.04, p$ $=0.919$ ) between total fluoride in soil with conductivity, salinity and TDS, respectively. Therefore, no correlation between total fluoride and the three parameters were obtained.

The maximum water soluble fluoride was obtained in Alem Tena and the minimum was in Addis Ababa University Arat Killo Campus, but the maximum conductivity, salinity and TDS was found in Zuway and the minimum was obtained in Mojo. The correlation coefficients of water soluble fluoride in soil with conductivity, salinity and TDS are $(r=0.56, p=0.096, r=$ $0.06, p=0.266, r=0.56, p=0.096)$, respectively. Relative to total fluoride water soluble fluoride have moderate positive correlation with the three parameters. It may be because the soluble fluoride increases the total ions in soil than the complex form of fluoride.

Correlations of metals with fluoride, $\mathrm{pH}$, conductivity, salinity and TDS

The relationship between fluoride and other metal elements in soil samples was investigated. As shown in Table 4, positive correlation between total fluoride and $\mathrm{Mg}, \mathrm{Ca}$ and $\mathrm{Cu}$ was found in soils. Coefficients of correlation were $0.22,0.12$ and 0.83 , respectively, and negative correlation between total fluoride and $\mathrm{Na}, \mathrm{K}, \mathrm{Cr}, \mathrm{Mn}, \mathrm{Co}, \mathrm{Ni}, \mathrm{Fe}$ and $\mathrm{Zn}$. Coefficients of correlation were $-0.36,-0.11,-0.60,-0.14,-0.45,-0.11,-0.73$ and -0.19 , respectively. The degree of correlation of total fluoride with metals are: highly positive correlation with $\mathrm{Cu}(\mathrm{r}>0.7)$ and highly negative correlation with $\mathrm{Fe}(\mathrm{r}<-0.7)$. The degree of correlation between total fluorides with $\mathrm{Na}, \mathrm{Cr}$ and $\mathrm{Co}$ is moderate negative correlation $(\mathrm{r}=-0.3$ to -0.7$)$. Total fluoride has also weak negative and positive correlation with $\mathrm{Mg}, \mathrm{Ca}, \mathrm{K}, \mathrm{Mn}, \mathrm{Ni}$ and $\mathrm{Zn}(\mathrm{r}=-0.3$ to 0.3$)$.

The correlation between water soluble fluoride and metals are shown in Table 4. Positive correlation between water soluble fluoride and $\mathrm{Na}, \mathrm{Mg}, \mathrm{K}$ and $\mathrm{Fe}$ was obtained in soils. Coefficients of correlation were $0.21,0.37,0.64$ and 0.08 , respectively, and negative correlation between water soluble fluoride and $\mathrm{Ca}, \mathrm{Cr}, \mathrm{Mn}, \mathrm{Co}, \mathrm{Ni}, \mathrm{Cu}$ and $\mathrm{Zn}$. Coefficients of correlation, $-0.11,-0.53,-0.21,-0.02,-0.13,-0.35$, and -0.12 , respectively. The degree of correlation between water soluble fluorides with metals are: water soluble fluoride has moderate positive correlation ( $\mathrm{r}=0.3$ to 0.7$)$ with $\mathrm{Mg}$ and $\mathrm{K}$, and moderate negative correlation $(\mathrm{r}=-0.3$ to -0.7$)$ with $\mathrm{Cr}$ and $\mathrm{Cu}$. Water soluble fluoride also weak positive and negative correlation with $\mathrm{Na}, \mathrm{Ca}$, $\mathrm{Mn}, \mathrm{Co}$, $\mathrm{Ni}$ and $\mathrm{Zn}(\mathrm{r}=-0.3$ to 0.3$)$.

The solubility of fluoride increases as $\mathrm{Na}$ concentration increases and $\mathrm{Ca}$ and $\mathrm{Mg}$ concentration decreases [24]. As a result, the highest water soluble fluoride was obtained in Alem-Tena sample. The highest concentration of $\mathrm{Ca}$ was also obtained in Alem-Tena and $\mathrm{Mg}$ and $\mathrm{Na}$ concentration in this site was comparable with other site. The highest concentration of water soluble fluoride in the site may be due to highest concentration of $\mathrm{K}$ and also form fluoride rich irrigation water. The levels of total fluoride in lower altitude of the site (Zuway, Adami-Tullu and Bulbulla) soil were excess the normal fluoride concentration of the soil 
reported in [21]. This may be because of the highest levels of $\mathrm{Mg}$ in Zuway, the lower concentration of $\mathrm{Na}$ in Adami-Tullu and Bulbulla and high concentration of $\mathrm{Ca}$ in Bulbulla.

Table 4. Correlation coefficients between metals with fluoride (both water soluble and total) and other parameters ( $\mathrm{pH}$, conductivity, salinity and TDS) in soil samples.

\begin{tabular}{|l|c|c|c|c|c|c|c|c|c|c|c|}
\hline & $\mathrm{Na}$ & $\mathrm{Mg}$ & $\mathrm{K}$ & $\mathrm{Ca}$ & $\mathrm{Cr}$ & $\mathrm{Mn}$ & $\mathrm{Co}$ & $\mathrm{Ni}$ & $\mathrm{Cu}$ & $\mathrm{Fe}$ & $\mathrm{Zn}$ \\
\hline $\begin{array}{l}\text { Total } \\
\text { fluoride }\end{array}$ & -0.36 & 0.22 & -0.11 & 0.12 & -0.60 & -0.14 & -0.45 & -0.11 & 0.83 & -0.73 & -0.19 \\
\hline $\begin{array}{l}\text { Water } \\
\text { soluble } \\
\text { fluoride }\end{array}$ & 0.21 & 0.37 & 0.64 & -0.11 & -0.53 & -0.21 & -0.02 & -0.13 & -0.35 & 0.08 & -0.12 \\
\hline $\mathrm{pH}$ & 0.12 & 0.99 & 0.48 & -0.70 & -0.29 & -0.36 & -0.28 & -0.30 & -0.18 & -0.49 & 0.25 \\
\hline Conductivity & 0.27 & 0.90 & 0.54 & -0.64 & -0.16 & -0.31 & -0.21 & -0.41 & 0.05 & -0.39 & 0.12 \\
\hline Salinity & 0.30 & 0.70 & 0.45 & -0.75 & 0.0 & -0.23 & 0.02 & -0.57 & 0.21 & -0.09 & 0.30 \\
\hline TDS & 0.27 & 0.90 & 0.54 & -0.64 & -0.16 & -0.31 & -0.21 & -0.41 & 0.05 & -0.39 & 0.12 \\
\hline
\end{tabular}

The correlations of metals with other parameters ( $\mathrm{pH}$, conductivity, salinity and TDS) in soil almost have similar trend except $\mathrm{Cr}$ and $\mathrm{Co}$ has positive correlation with salinity and negative correlation with other three parameters; $\mathrm{Cu}$ has negative correlation with $\mathrm{pH}$ and positive correlation with other parameters. Metals have negative correlation with $\mathrm{Ca}, \mathrm{Mn}, \mathrm{Ni}$ and $\mathrm{Fe}$ and positive correlation with $\mathrm{Na}, \mathrm{Mg}, \mathrm{K}$ and $\mathrm{Zn}$. There degrees of correlation are: $\mathrm{Mg}$ has highly positive correlation with all the four parameters and $\mathrm{Ca}$ has highly negative correlation with salinity. $\mathrm{K}$ with all four parameters and $\mathrm{Na}$ with salinity have moderate positive correlation and $\mathrm{Ca}$ and $\mathrm{Fe}$ with $\mathrm{pH}$, conductivity and TDS and $\mathrm{Ni}$ with conductivity, salinity and TDS have moderate negative correlation. $\mathrm{Na}$ with $\mathrm{pH}$, conductivity and TDS, $\mathrm{Cr}, \mathrm{Mn}, \mathrm{Co}, \mathrm{Cu}$ and $\mathrm{Zn}$ with all four parameters, $\mathrm{Ni}$ with $\mathrm{pH}$ and $\mathrm{Fe}$ with salinity has weak positive and negative correlation. The relationship between fluoride and other metals in water samples was investigated. As shown in Table 5, positive correlation between fluoride and $\mathrm{Na}, \mathrm{K}, \mathrm{Ca}, \mathrm{Cr}, \mathrm{Co}, \mathrm{Fe}$ and $\mathrm{Cu}$ was determined in the water samples. Coefficients of correlation were $0.43,0.34,0.25,0.18,0.08$, 0.05 and 0.09 , respectively, and negative correlation between fluoride and $\mathrm{Mg}, \mathrm{Mn}, \mathrm{Ni}$ and $\mathrm{Zn}$. Coefficients of correlation were $-0.44,-0.01,-0.10$ and -0.13 , respectively. The degree of correlation of fluoride with metals are: fluorides has moderate positive correlation with $\mathrm{Na}$ and $\mathrm{K}$ and moderate negative correlation with $\mathrm{Mg}$. Fluoride in water also has no correlation with $\mathrm{Ca}$, $\mathrm{Cr}, \mathrm{Mn}, \mathrm{Co}, \mathrm{Ni}, \mathrm{Cu}, \mathrm{Fe}$ and $\mathrm{Zn}$.

Table 5. Correlation coefficients between metals with fluoride and other parameters ( $\mathrm{pH}$, conductivity, salinity and TDS) in water samples.

\begin{tabular}{|l|c|c|c|c|c|c|c|c|c|c|c|}
\hline & $\mathrm{Na}$ & $\mathrm{Mg}$ & $\mathrm{K}$ & $\mathrm{Ca}$ & $\mathrm{Cr}$ & $\mathrm{Mn}$ & $\mathrm{Co}$ & $\mathrm{Ni}$ & $\mathrm{Cu}$ & $\mathrm{Fe}$ & $\mathrm{Zn}$ \\
\hline Fluoride & 0.43 & -0.44 & 0.34 & 0.25 & 0.18 & -0.006 & 0.08 & -0.10 & 0.05 & 0.09 & -0.13 \\
\hline $\mathrm{pH}$ & 0.50 & 0.03 & 0.11 & 0.19 & 0.32 & 0.34 & -0.09 & -0.04 & 0.60 & -0.10 & 0.32 \\
\hline Conductivity & 0.70 & 0.03 & 0.67 & 0.58 & 0.57 & 0.36 & 0.16 & 0.12 & -0.17 & 0.24 & -0.24 \\
\hline Salinity & 0.80 & 0.003 & 0.63 & 0.67 & 0.49 & 0.48 & 0.004 & 0.24 & -0.14 & 0.28 & -0.32 \\
\hline TDS & 0.70 & 0.02 & 0.67 & 0.58 & 0.57 & 0.36 & 0.16 & 0.12 & -0.17 & 0.24 & -0.24 \\
\hline
\end{tabular}

\section{Correlations of metals between water and soil samples}

The relationship between metals in water and soil samples is shown in Table 6. Some metals ( $\mathrm{Ca}, \mathrm{Cr}, \mathrm{Mn}, \mathrm{Co}, \mathrm{Ni}$ and $\mathrm{Fe}$ ) have positive correlation, but other metals $(\mathrm{Mg}, \mathrm{K}, \mathrm{Cu}$ and $\mathrm{Zn}$ ) have negative correlation in water and soil samples. The degrees of correlation of $\mathrm{Cr}$ and $\mathrm{Fe}$ in 
soil with that in water samples are moderate positive and $\mathrm{Na}, \mathrm{Mg}, \mathrm{Cu}$ and $\mathrm{Zn}$ are negative moderate correlation. Some metals ( $\mathrm{K}, \mathrm{Ca}, \mathrm{Mn}, \mathrm{Co}$ and $\mathrm{Ni}$ ) in soil have no correlation with that in water samples. The concentration of each individual metal in soil is higher relative to corresponding metals in the water.

Table 6. Correlation coefficients of metals between water and soil samples.

\begin{tabular}{|l|c|c|c|c|c|c|c|c|c|c|c|}
\hline Metal & $\mathrm{Na}$ & $\mathrm{Mg}$ & $\mathrm{K}$ & $\mathrm{Ca}$ & $\mathrm{Cr}$ & $\mathrm{Mn}$ & $\mathrm{Co}$ & $\mathrm{Ni}$ & $\mathrm{Cu}$ & $\mathrm{Fe}$ & $\mathrm{Zn}$ \\
\hline $\begin{array}{l}\text { Correlation } \\
\text { coefficient (r) }\end{array}$ & -0.59 & -0.40 & -0.26 & 0.15 & 0.34 & 0.08 & 0.29 & 0.03 & -0.36 & 0.51 & -0.33 \\
\hline
\end{tabular}

Comparison of fluoride levels in this study with literature values

The fluoride concentration in this study has wide variation between sample sites relative to the reported values in the literature; it may because of the variation of soil type, climate, altitude and so on. Except the value reported by US NAS [25], Washington DC, America and Smith and Hodge [26], fluoride in American soil is lower than this study, while others such as Toma et al. [27], Moldova; Shomar et al. [28], Israel; Zhang et al. [29], China and others have comparable value of total fluoride with this study. The water soluble content of soil in this study is a bit higher than that of reported in literature, but comparable values also reported in America [25] and New Zealand [30].

The fluoride concentration in water sample is highly dependent on the water source. The river water of this study has slightly higher concentration of fluoride than the other study of Ethiopia reported in literature [31]. Except Israel [28] and Ethiopia [31], slightly higher concentration, the fluoride concentration of ground water in this study is lied the range of reported values in the literature. The fluoride concentration in lake of this study varied widely between sample sites, it may depend on different altitudes of Ethiopian Rift Valley. But the fluoride concentration lied in the range of values reported in Kenya [32], slightly higher than that reported in India [32] and some sites are comparable with that reported in Ethiopia [31].

\section{Comparison of metal levels in this study with literature values}

The natural content of metals in the soil is directly related to the mineralogical and granulometrical composition and the origin of the matrix soil. The metal concentrations in soil varied in wide range. From the major metals, the content of Na was comparable to that reported in USA [33] and lower than that reported in Pakistan [34]. K was lower than that reported in USA [33] and Pakistan [34]. Ca was lower than that reported in USA and higher than that reported in Pakistan. The values of $\mathrm{Mg}$ in the literature lie in the range of this study.

The trace metal Mn in Turkey [35], Fe in USA [33], Zn in Ireland [36] and Turkey [35], Cu in USA, Turkey and Ireland and Cr in USA and Turkey are comparable to the values of fluoride in soil obtained in this study. But Mn and Zn in USA are higher and Fe in Turkey, Ni and Co in USA and Turkey are lower than the values compared to the result obtained in this study.

The concentration of $\mathrm{Na}$ in this study is lower than those reported in literature. $\mathrm{K}$ is bit higher in this study of the well water than Israel [28] and comparable in the lower end of the range reported in Kenya [32] and India [32,37]. The concentration of $\mathrm{Ca}$ in the lake of this study lie in the range of reported in Kenya [32], but bit higher in the well of this study relative to the reported value of Israel [28] and India [37]. Mg in the lake of this report is lie in the range of reported literature value of Kenya and India [32] and also comparable in the well of this study with literature values.

$\mathrm{Mn}$ and Fe content in this study are comparable with that reported in literature of Nigeria [38]. $\mathrm{Zn}$ in the river of this study is comparable with the literature values reported in Nigeria 
[38], but bit lower than that reported in the surface water of the same place in Nigeria [39]. Ni concentration in this study is higher than the result reported in Nigeria [39]. Co in the lake water is bit higher than the reported value in Ethiopia [40]. $\mathrm{Cu}$ in lake water of this study is also higher than reported in Ethiopia [40], but comparable to the result reported in Nigeria [38, 39]. $\mathrm{Cr}$ concentration is bit higher in this study than the literature value reported in Nigeria [38], Ethiopia [40] and India [37].

\section{Limitations of the study}

The samples for the present study comprised only eleven soil and water samples because of budget constraint. The number of sample is a very small proportion of the entire area of Rift Valley farm land. Therefore, studies with much larger sample size covering wider area would be required to ensure appropriate generalization of the findings of the study. Because of time and budget limitation only soil and water samples were analyzed but vegetation analysis for fluoride elicited better for improving findings.

\section{CONCLUSION}

The water soluble fluoride in soil was within normal fluoride levels of soil. This indicates that the fluoride accumulation in vegetation have no impact for human health. The level of fluoride in the irrigation water samples was below WHO limit of fluoride in irrigation waters, indicating absence of toxicity by the irrigation water to some crops and animals.

The concentration of metals in soil samples in this study was in the following order $\mathrm{Fe}>\mathrm{Ca}$ $>\mathrm{Mg}>\mathrm{Na}>\mathrm{K}>\mathrm{Ni}>\mathrm{Mn}>\mathrm{Co}>\mathrm{Zn}>\mathrm{Cr}>\mathrm{Cu}$. The order fit with the relative abundance of metals in earths crest. The concentration pattern of metals in water was in the following decreasing order as $\mathrm{Ca}>\mathrm{Mg}>\mathrm{Na}>\mathrm{Fe}>\mathrm{Ni}>\mathrm{Mn}>\mathrm{K}>\mathrm{Co}>\mathrm{Zn}>\mathrm{Cu}>\mathrm{Cr}$. Relative to General Guidelines for Irrigation Water Used in Plant Production, this result exceeds the reported optimum range for some metals.

The $\mathrm{pH}$ of soils fell in neutral region (6.53-8.43), which indicates absence of or negligible effect on fluoride solubility and its availability for vegetation uptake because $\mathrm{pH}$ exerts significant effect on fluoride solubility on acidic and basic soils. The other three parameters (conductivity, salinity and TDS) have strong positive correlation with fluoride in water samples and moderate positive correlation with water soluble fluoride in soil samples, but no significant correlation with total fluoride in soil.

Fluoride concentrations in water have strong positive correlation with water soluble fluoride in soil, but weak positive correlation with total fluoride in soil. The percentage of total fluoride extracted with water from the soil was very small (0.52-4.3\%) with no significant correlation.

The correlation of metals with total and water soluble fluoride indicated that the low solubility of fluoride in soil sample may be due to high concentration of $\mathrm{Ca}, \mathrm{Cu}$ and $\mathrm{Mg}$ and low concentration of $\mathrm{Na}, \mathrm{K}$, and $\mathrm{Fe}$. Except, $\mathrm{Na}$ and $\mathrm{K}$ which have moderate positive correlation with fluoride, other metals have no significant correlation with fluoride in water sample. Generally, the concentrations of major metals in soil have vital input in the fluoride solubility than trace metals.

The present study provides interesting information about fluoride concentration in soil and irrigation waters and its correlation with selected metals. Aluminum facilitates fluoride transportation for plant uptake from soil, and hence we recommend the analysis of $\mathrm{Al}$ in soils. Analysis of fluoride in air and vegetation deserves further study. 
Correlation among fluoride and metals in irrigation water and soils of Ethiopian Rift Valley 243

\section{AKNOWLEDGEMENTS}

The authors express their gratitude to the Department of Chemistry, Addis Ababa University (Ethiopia) for providing the laboratory facilities. Elias Gizaw is thankful to the Ministry of Education (Ethiopia) for sponsoring his study.

\section{REFERANCES}

1. Okibe, F.G.; Ekanem, E.J.; Paul, E.D.; Shallangwa, G.A.; Ekwumemgbo, P.A.; Sallau, M.S.; Abanka, O.C. Aust. J. Basic Appl. Sci. 2010, 4, 779.

2. Madhavan, N.; Subramanian, V. J. Environ. Monit. 2002, 4, 821.

3. Ayenew, T. Afr. Water J. 2007, 1, 80.

4. Reimann, C.; Bjorvatn, K.; Frengstad, B.; Melaku, Z.; Tekle-Haimanot, R.; Siewers, U. Sci. Total Environ. 2003, 311, 65.

5. Tekle-Haimanot, R.; Melaku, Z.; Kloos, H.; Reimann, C.; Fantaye, W.; Zerihun, L.; Bjorvatn, K. Sci. Total Environ. 2006, 367, 182.

6. Tamene, G. Fluoride contamination and treatment in the Ethiopian Rift Valley, Ministry of Water Resources: Addis Ababa, Ethiopia; 2006.

7. Bjorvatn, K.; Reimann, C.; Ostvold, S.H.; Tekle-Haimanot, R.; Melaku, Z.; Siewers, U. Oral Health Prev. Dent. 2003, 1, 141.

8. Gizaw, B. J. Afr. Earth Sci. 1996, 22, 391.

9. Errico, M.; Desogus, F.; Mascia, M.; Tola, G.; Dendena, L. Chemical Papers 2006, 60, 460.

10. Moges, G.; Zewge, F.; Socher, M. J. Afr. Earth Sci. 1996, 21, 479.

11. Baissa, T.; Suwanarit, A.; Osotsapar, Y.; Sarobol, E. Kasetsart Journal (Natural Science) 2007, 41, 84.

12. Hengsdijk, H.; Jansen, H. Wageningen: Plant Research International, January 2006, Note 375 .

13. Malde, M.K.; Scheidegger, R.; Julshamn, K.; Bader, H.-P. Environ. Health Persp. 2011, $119,579$.

14. Tegegne, B.; Chandravanshi, B.S.; Zewge, F. Bull. Chem. Soc. Ethiop. 2013, 27, 179.

15. Atlabachew, M.; Chandravanshi, B.S.; Zewge, F.; Redi, M. Toxicol. Environ. Chem. 2011, 93, 32.

16. Weldegebriel, Y.; Chandravanshi, B.S.; Wondimu, T. Ecotox. Environ. Saf. 2012, 77, 57.

17. Kitata, R.B.; Chandravanshi, B.S. Bull. Chem. Soc. Ethiop. 2012, 26, 27.

18. Mekonnen, K.N.; Ambushe, A.A.; Chandravanshi, B.S.; Abshiro, M.R.; McCrindle, R.I. Toxicol. Environ. Chem. 2012, 94, 1980.

19. McQuaker, N.R.; Gurney, M. Anal. Chem. 1977, 49, 53.

20. Hur, J.; Yimb, S.; Schlautman, M.A. J. Environ. Monit. 2003, 5, 837.

21. Jakovljevic, M.; Blagojevic, S.; Antic-Mladenovic, S. J. Agric. Sci. 2002, 47, 121.

22. World Health Organization Guidelines for Drinking Water Quality Health Criteria and Other Supporting Information, World Health Organization: Geneva; 1984.

23. Robbins, J. Irrigation Water for Greenhouses and Nurseries, Ornamentals, Horticulture Department, University of Arkansas Division of Agriculture, 1994.

24. Beg, M.K. Geospatial analysis of fluoride contamination in ground water of Tamnar area, Raigarh District, Chhattisgarh State, PhD Diss., International Institute for Geo-information Science, Dehradun, India, 2009.

25. US NAS. Fluorides, National Academy of Sciences: Washington DC: 1997.

26. Smith, F.A.; Hodge, H.C. Crit. Rev. Environ. Cont. 1979, 8, 293.

27. Toma, S.; Kreidman, J.; Vedina, O.; Veliksar, S. Fluoride 1999, 32, 67. 
28. Shomar, B.; Muller, G.; Yahya, A.; Askar, S.; Sansur, R. J. Water Health 2004, 2, 23.

29. Zhang, C.; Li, Z.; Gu, M.; Deng, C.; Liu, M.; Li, L. Plant, Soil Environ. 2010, 56, 282.

30. Loganathan, P.; Hedley, M.J.; Wallace, G.C.; Roberts, A.H.C. Environ. Pollut. 2001, 115, 275.

31. Smedley, P.L. Fluoride in Ethiopian Groundwater, Report from a fact-finding visit, British Geological Survey: Addis Ababa, Ethiopia; 2008.

32. Njenga, J.W. Asian J. Water Environ. Pollut. 2004, 1, 87.

33. Gritsan, N.P.; Miller, G.W.; Schumatkov, G.G. Fluoride 1995, 28, 180.

34. Tariq, S.R.; Shaheen, N.; Khalique, A.; Shah, M.H. Environ. Monit. Assess. 2010, 166, 303.

35. Tuzen, M. Microchem. J. 2003, 74, 289.

36. McGrath, D.; Tunney, H. J. Plant Nutr. Soil Sci. 2010, 173, 548.

37. Raja, G.; Venkatesan, P. E-J. Chem. 2010.7, 473.

38. Eletta, O.A.A. Int. J. Phys. Sci. 2007, 2, 56.

39. Haruna, A.; Uzairu, A.; Harrison, G.F.S. Elect. J. Environ. Agric. Food Chem. 2009, 8, 500.

40. Kebede, A.; Wondimu, T. Bull. Chem. Soc. Ethiop. 2004, 18, 119. 